\section{Europe asks UK to reject cloning approval . . .}

Members of the British Parliament have been asked by their European colleagues to reject a government recommendation from a UK body that has proposed changes to legislation on embryo re search to allow the cloning of human embryos using cell nuclear transfer.

The call has come from the European Parliament-the legislative body that approves the activities of the European Commission-in a resolution passed narrowly last month that also asks for a ban on human cloning to be included in the EU Charter of Fundamental Rights, and for such a ban to be enshrined in national legislation across Europe.

British MPs are to be allowed a free votelater this year on their government's proposal, based on a recommendation from a panel headed by its chief medical officer, Liam Donaldson, that it should amend the Human Fertilization and Embryology Act of 1990 to allow research into 'therapeutic cloning' (Nature Med. 6, 950; 2000).

The Donaldson panel had concluded that the potential medical benefits of such research outweighed the ethical concerns raised by the cloning of embryos for research purposes. But at the European level, political sentimentswayed largely by strong opposition from Catholic countries (see box, opposite page)-is al ready going the other way.

All forms of embryo research are already excluded from funding from the European Commission's Fifth Framework program, its five-year research funding program, the most recent of which started this year.

There was some support for the British position during the debate in the European Parliament, which took place 7 September. French MEP Francoise Grossetête, for example, described the potential benefits for individuals suffering from Alzheimer and Parkinson disease, whereas her German and Dutch colleagues Evelyne Gebhardt and Elly Plooijvan Gorsel both argued that even if such research was outlawed in Europe, it was likely to take place elsewhere, with any resultant medical therapies later marketed in Europe.

Reflecting this moderate approach, the parliament rejected a resolution

\section{. . . while US scientists push for derivation}

Having won a small victory in being allowed to experiment on already derived human embryonic stem cells, or human pluripotent stem cells (hPSCs), using government money, US-based scientists are now beginning another battle that would place them on par with their UK counterparts. They are seeking approval to derive their own hPSCs for experimentation.

The differences in scope of the guidelines released in each country within the last few weeks (see http://www. nature.com/nm/biomedical_news/

082900_kb.html) means that the UK could pull ahead of the US in this field of research. Although the US National Institutes of Health (NIH) will fund research on stem cells lines, it will not support their derivation from embryos-a situation that creates a drawback for US researchers, because not knowing the quality and history of the cells used in experiments with could affect experiments, explains Stanford researcher and Noble laureate Paul Berg.

Also, the fact that NIH-funded researchers cannot do research using pluripotent stem cells that were derived by somatic cell nuclear transfer means that some pre-existing cell lines are off limits for study. "It's a handicap. It means that we can't explore all possible uses for these cells...some researchers may have experiments in mind that the Brits can do that we can't," says John Gearhart of Johns Hopkins University.

So last month, the US Senate held hearings and prepared to vote on the Stem Cell Research Act of 2000, a bill introduced by Senators Arlen Specter (RPA) and Tom Harkin (D-IA) that would allow NIH-funded researchers to derive their own cells from discarded embryos.

The hearings began by reiterating the potential value of adult stem cells. Gerald Fischbach (director of the National Institute of Neurological Disorders and Stroke) and Allen Spiegel (director of the National Institute of Diabetes and Digestive and Kidney Diseases) gave testimony, as did two scientists opposed to research on human embryonic stem cells: David Prentice, professor of life sciences at Indiana State University and Micheline MatthewsRoth of Harvard M edical School.

Debate centered on whether stem tabled by the Socialist and Liberal groups to set up a temporary committee on bioethics to examine the issue of therapeutic cloning, arguing that its views had al ready been expressed in previous resolutions.

But strong feelings were equally expressed by opponents of therapeutic cloning. Another French MEP, Nicole Thomasmauro, described a move to authorize experimentation on human embryos as "monstrous," and her Italian colleague Francesco Fiori rejected it as an "affront to civilization." A resolution calling on members of the British Parliament to "exercise their votes of conscience" and reject the UK government's proposal was approved by 237 votes to 230, with 43 abstentions.

Meanwhile the European Commission is awaiting a report on therapeutic cloning from the European Group on Ethics, an advisory body set up by the parliament two years ago in the wake of the debate on the patenting of biotechnology inventions. The report, due out next month, is expected to be important in determining the commission's approach to the issue.

\section{David Dickson, London}

cells derived from adult tissue were a suitable substitute for embryonic stem cells. Stem cells for some tissue types, such as cardiac stem cells or pancreatic islet cells, have not yet been identified in adult humans. Adult stem cells can also only be obtained through surgical removal of tissue, and may not have the same capacity to multiply as the younger embryonic stem cells.

However, several publications in the past year have reported that cells derived from bone marrow can be induced to differentiate into neuronal cells and liver cells. "The scientific literature overwhelmingly demonstrates adult stem cells are al ready fulfilling the goals we hoped for with embryonic cells, making destruction of human embryos completely unjustifiable," argued Prentice. "Adult cells do have the ability to differentiate and proliferate," admitted Fischbach, "But I think these are early reports and the conversion to a neuronal phenotype is not complete. The overwhelming evidence is that they do not generate sufficient numbers of nerve cells to be useful in the brain." Congress was due to vote on the issue as Nature Medicine went to press.

Kristine Novak, New York 